\title{
Synchronous serous carcinoma arising in adenomyosis and small cell carcinoma of ovary - pulmonary type (SCOOPT): a case report and literature review
}

\author{
Qiuyang Jing \\ Department of Pathology, West China Second Hospital of Sichuan University \\ Ying He ( $\sim$ heying626@163.com) \\ Department of Pathology, West China Second Hospital of Sichuan University
}

\section{Case Report}

Keywords: serous carcinoma, adenomyosis, malignant transformation, small cell carcinoma of the ovary, pulmonary type, immunohistochemistry

Posted Date: February 22nd, 2022

DOI: https://doi.org/10.21203/rs.3.rs-1374888/v1

License: (c) (i) This work is licensed under a Creative Commons Attribution 4.0 International License. Read Full License 


\section{Abstract}

Background: Serous carcinoma arising in adenomyosis is rare, only 8 cases have been reported in the literature. Primary small cell carcinoma of ovary - pulmonary type (SCOOPT) is a rare, aggressive entity associated with poor outcomes and limited treatment options. The two malignant tumors synchronously happen at one patient has never been reported before.

Case presentation: We summarized and analyzed the clinicopathological features of 1 serous carcinoma arising in adenomyosis synchronous with SCOOPT and reviewed the literature. A 60-year-old postmenopausal woman presented to our hospital with abdominal distension, abdominal pain, and constipation. Colonoscopy and computed tomography (CT) scan of pulmonary showed no abnormalities. Ultrasonography and CT scan revealed a solid-cystic mass in the pelvic cavity, slightly thickened uterine myometrium at the fundus with heterogeneous echo. A total abdominal hysterectomy, bilateral salpingo-oophorectomy, and pelvic and para-aortic lymphadenectomy were performed. The final pathology showed serous carcinoma originating from adenomyosis, while the eutopic endometrium and both fallopian epithelia were identified with no cancer. The solid-cystic mass in the right ovary is diagnosed with SCCOPT and metastasis to the myometrium of the uterus. The prognosis of previously reported cancers of adenomyosis origin and SCOOPT were both poor, while our case was alive without disease during the 6-month follow-up.

Conclusion: We believe this case report will expand our recognition of the coexistence of serous carcinoma arising in adenomyosis with small cell carcinoma of the ovary-pulmonary type (SCOOPT).

\section{Background}

Adenomyosis is defined as ectopic endometrial glands and stroma invades myometrium. Adenomyosis is a common benign gynecological disease in hysterectomy specimens and often coexistence with other diseases, such as endometrioid adenocarcinoma, leiomyoma, etc. The malignant transformation of adenomyosis was first reported by Rolly in 1897[1], only dozens of cases have been reported since then and most of them are malignant transformation into endometrial adenocarcinoma. [2-6]. However, serous adenocarcinoma originating from adenomyosis was first reported by Griffin in 1996[7] and only 8 cases have been reported so far $[3,6,8-11]$. Due to the rarity of serous adenocarcinoma originating from adenomyosis and current reports are mostly individual cases, we currently know little about the etiology, pathogenesis, and genetic alteration of this disease.

The gynecologic tract, including the cervix, endometrium, ovary, fallopian tube, vagina, and vulva, is one of the extrapulmonary systems where extrapulmonary small cell carcinoma (EPSCC) occur frequently, representing less than $1 \%$ of all gynecologic malignancies $[12,13]$. Small cell carcinoma of the ovary (SCCO) is an uncommon, highly aggressive cancer with an incidence of less than $1 \%$ of ovarian tumors.[14] Small cell carcinoma of the ovary is consists of two different types, the hypercalcemic type (SCCOHT) and the pulmonary type (SCCOPT). SCCOHT is often associated with hypercalcemia, while the SCCOPT shows the characteristic morphologic features of lung small cell carcinoma.[12]

Serous carcinoma arising from adenomyosis and SCCOPT both are rare tumors of the female genital tract. We have less knowledge about these two types of tumors, let alone both tumors occur in the same patient at the same time. Herein, we reported the first case of this two cancers simultaneously occurred at one petient and analyzed the previous literature about serous adenocarcinoma originating from adenomyosis. We believe that this report will increase our understanding of the two diseases.

\section{Case Presentation}

\section{Clinical features and findings in the operation:}

A 60-year-old postmenopausal woman attended the local community hospital, gravida 2, para 1, complained of abdominal pain, abdominal distention, and constipation for about 1 month. Her gastroenterological endoscope at the local community hospital showed no abnormalities. Ultrasonography found a solid- cystic heterogeneous mass in the pelvic cavity and indicate it may be derived from the adnexa. (Fig. 1) She had dyspnea due to abdominal distension a few days later, then she underwent abdominal puncture decompression treatment in the emergency department of our hospital. 
The patient had regular menstruation in the past and was menopausal 4 years ago. She denied receiving hormone replacement therapy or the existence of breast cancer. The patient was diagnosed with hypertension 10 years ago and treated with amlodipine orally, and both her parents and siblings have had a history of hypertension. She had a negative cervical smear one month ago.

Pelvic examination showed a moderately enlarged uterus and an unmovable mass about $9 \mathrm{~cm}$ in the right adnexa. CT scan of the pelvic and abdomen cavity revealed an irregular solid-cyst masses in the right adnexa area, with sizes of $4.7 \mathrm{~cm} \times 3.4 \mathrm{~cm} \times 2.1 \mathrm{~cm}$ and $9.3 \mathrm{~cm} \times 7.6 \mathrm{~cm} \times 6.6 \mathrm{~cm}$, respectively. The contrast-enhanced CT scan showed the tumor with heterogeneous enhancement and the "ovarian blood vessel pedicle" sign, and the boundary between the serosal surface of the uterus and the lateral adnexa area is unclear. The peritoneum and the omentum majus are thickened, and large amount of ascites can be seen in the pelvic and abdominal cavity. No abnormalities were showed in the liver, spleen, pancreas, and kidneys under the ultrasonography. The contrast-enhanced CT scan of the lung showed no mass or ground-glass opacity. Total abdominal hysterectomy and bilateral salpingo-oophorectomy (TAHBSO) were initially performed. The serum CA125 is $284.2 \mathrm{U} / \mathrm{ml}$, serum AFP is $16.1 \mathrm{ng} / \mathrm{ml}$, and serum calcium is $2.06 \mathrm{mmol} / \mathrm{L}$ (normal $2.15-2.70 \mathrm{mmol} / \mathrm{L}$ ).

The surface of the uterus and left ovary were found to be smooth during the operation and the left ovary is size $4.0 \mathrm{~cm} \times 4.0 \mathrm{~cm} \times 3.0 \mathrm{~cm}$. The right ovary adheres to the posterior lobe of the broad ligament and the pelvic floor and is about $10.0 \mathrm{~cm} \times 8.0 \mathrm{~cm} \times 8.0 \mathrm{~cm}$. A solid cystic mass was seen in the right ovary. The solid part of the mass was fish-like, fragile, and easy to hemorrhage. The cystic cavity was filled with dark red cyst fluid. The fallopian on both sides were slightly edema.

\section{Gross pathology:}

A solid-cystic, gray-tan irregular mass about $11.0 \mathrm{~cm} \times 7.0 \mathrm{~cm} \times 6.0 \mathrm{~cm}$, with a fibrous capsule, replaced the right ovary. The cut surface of the mass is gray-tan, with hemorrhage, cyst formation, and necrosis. The mass was predominantly solid, with scattered small cysts, ranging from $0.1 \mathrm{~cm}$ to $0.5 \mathrm{~cm}$ in diameter. The serosal surface of both fallopian tubes is smooth, and no abnormalities were found in the lumen or fimbria. The myometrium at the fundus is slightly thickened and harder than the surrounding myometrium, with gray-white cut surface. There were no polyps, rough areas, or masses in the eutopic endometrium and endocervical canal. The specimens of the left adnexa, the right fallopian tube, the endometrium, and the cervix were all extensively sectioned for histopathological examination.

\section{Microscopic pathology and immunohistochemical staining}

Histologically, the tumor cells of the right ovary are grown in nests and organ-like, showing the typical microsrocpic structure of small cell neuroendocrine carcinoma. The tumor is comprised of monomorphic small cells with indistinct cellular borders, ovoid nuclei with vesicular chromatin, hyperchromatic nucleoli, scanty cytoplasm, and brisk mitotic activity. (Fig. 2) Lymphovascular space invasion can be seen around the tumor.

Microscopically, ectopic endometrium glandular and stroma were found in the thickened myometrium of the fundus, supportting the diagnosis of adenomyosis. Within the adenomyosis, serous carcinoma was present with a destructive growth pattern (Fig. 3) and desmoplastic reaction. The neoplastic glands were lined by markedly atypical, cuboidal to columnar cells with hyperchromasia, conspicuous nucleoli, and irregular nuclear membrane. The tumor component is located in the deep half of the myometrium and is adjacent to the serosal layer. Metastatic SCCOPT was found in the myometrium. Lymphovascular space invasion can also occasionally be found in the myometrium. There were no serous carcinoma, serous endometrial intraepithelial carcinoma (SEIC), or endometrial glandular dysplasia (EmGD) in the eutopic endometrium or the fallopian epithelial.

Immunohistochemical staining of the small cell carcinoma of the ovary showed diffuse positivity of SMARCA4, CD56, CgA, Syn (Fig. 2), and focal positivity of SF-1, on the other hand, EMA, Vim, FOXL-2, a-inhibin, CD10, CyclinD1, LCA, CD117, DOG-1, and SALL4 were all negative. The Ki67 proliferation index is about 95\%. Immunohistochemical staining of the serous carcinoma arising from adenomyosis showed diffuse positivity of EMA, PAX-8, and P53 (Fig. 3), while P16, ER, PR, WT-1, Vim, PTEN, CgA, and Syn were all negative. Both the ectopic endometrial glands and bilateral fallopian tube epithelium showed wild-type expression of P53 (Fig. 4).

No recurrence or metastasis occurred during the 6-month follow-up after the operation, and the patient is currently receiving chemotherapy at the local hospital. 


\section{Discussion}

Adenomyosis is a common disease in hysterectomy specimens, and its common symptoms include dysmenorrhea, and irregular menstruation, etc. Adenomyosis is histologically defined as the presence of ectopic endometrial glands and stroma within the myometrium. It is not uncommon for adenomyosis to merge with malignant tumors of the female genital, but the incidence of malignant transformation of adenomyosis is low[5]. The malignant transformation of adenomyosis is mostly endometrioid adenocarcinoma $[4,15,16]$. In contrast, the malignant transformation of adenomyosis into serous adenocarcinoma or clear cell adenocarcinoma is even rarer.[5, 17]

The widely agreed diagnostic criteria for malignant transformation of adenomyosis are the Sampson criteria and the Scott and Colman supplementary criteria. These criteria include the following $[2,18,19]$ : (1) there are endometrial glands and/or stromal cells exist deep in the myometrium to support the diagnosis of adenomyosis, or there are endometrial glands or stromal cells around the malignant lesions; (2) there is transformation evidence between benign and malignant glands structure, e.g., normal endometrial epithelium, borderline, and invasive carcinoma coexist.; (3) other sources of tumor invasion or metastasis are excluded, e.g., endometrium and other parts of the pelvis; (4) cancer tissue and ectopic endometrial tissue coexist in the same lesion. Due to the special diagnostic criteria of malignant transformation of adenomyosis, it is almost impossible to make an accurate diagnosis before the operation. Only complete pathological examination of all specimens after the operation can make the final diagnosis.

Our case meets all the diagnostic criteria mentioned above. In this case, clear ectopic endometrial glands and stroma can be seen between the myometrium, and the transition zone from benign glandular epithelium to serous adenocarcinoma can be seen. Based on the complete gross examination, microscopic examination, and appropriate immunohistochemistry staining, metastatic serous adenocarcinoma of endometrial, ovarian, or fallopian tube can be excluded.

The clinicopathological characteristics of serous adenocarcinoma originating from adenomyosis are presents in the Table 1. Most cases were occured in postmenopausal women[5]. The most common symptoms are irregular vaginal bleeding and abdominal discomfort. All reported cases underwent total abdominal hysterectomy and bilateral salpingo-oophorectomy, and most of them underwent lymph node dissection. There was a study about endometrial cancer arising in adenomyosis showed that it had a significantly poorer disease-free survival than endometrial cancer with adenomyosis (5-year rate, $\mathrm{P}=0.014$ ), and it is an independent prognostic factor for decreased disease-free survival $(P=0.001)$.[11] Machida et al. also found that the prognosis of endometrioid adenocarcinoma arising in adenomyosis was significantly worse than that of patients with endometrioid adenocarcinoma coexisting with adenomyosis.[20] On the contrary, Table 1 shows that the prognosis of serous carcinoma arising from adenomyosis seem to be good and the patients with prognostic information were all alive without recurrence at the end of follow-up. The completely opposite prognostic results of adenomyoisis malignant transformation of endometrioid adenocarcinoma and serous carcinoma may be due to the rarity of the latter and only few cases have been reported. Our case is only follow up for 6 months and is currently undergoing chemotherapy, so its data may not reflect the true prognosis of the disease.

Table 1. Clinicopathological characteristics of serous adenocarcinoma originating from adenomyosis in the previous literature 


\begin{tabular}{|c|c|c|c|c|c|c|c|}
\hline Author, time & $\begin{array}{l}\text { Case } \\
\text { no. }\end{array}$ & $\operatorname{Age}(\mathrm{y})$ & Complaint & $\begin{array}{l}\text { Findings in } \\
\text { the } \\
\text { adenomyosis }\end{array}$ & Operation & Follow-up & $\begin{array}{l}\text { Clinico- } \\
\text { pathological } \\
\text { features }\end{array}$ \\
\hline $\begin{array}{l}\text { Miriam } \\
\text { Griffin[7], } \\
1996\end{array}$ & 1 & 68 & $\begin{array}{l}\text { postmenopausal } \\
\text { bleeding. }\end{array}$ & $\begin{array}{l}\text { papillary } \\
\text { serous } \\
\text { carcinoma }\end{array}$ & TAH and BSO & NA & $\begin{array}{l}\text { Cervical smear } \\
\text { was positive for } \\
\text { adenocarcinoma. }\end{array}$ \\
\hline $\begin{array}{l}\text { Masafumi } \\
\text { Koshiyama[8], } \\
2002\end{array}$ & 2 & 69 & $\begin{array}{l}\text { postmenopausal } \\
\text { bleeding }\end{array}$ & $\begin{array}{l}\text { Papillary } \\
\text { serous } \\
\text { carcinoma }\end{array}$ & $\begin{array}{l}\text { TAH and BSO, } \\
\text { pelvic and para- } \\
\text { aortic } \\
\text { lymphadenectomy }\end{array}$ & $\begin{array}{l}96 \\
\text { months, } \\
\text { AWOD }\end{array}$ & EE-, PR-, P53+++ \\
\hline $\begin{array}{l}\text { Narges Izadi- } \\
\text { Mood[9], } \\
2007\end{array}$ & 3 & 61 & $\begin{array}{l}\text { postmenopausal } \\
\text { bleeding }\end{array}$ & $\begin{array}{l}\text { papillary } \\
\text { serous } \\
\text { carcinoma }\end{array}$ & THA and BSO & $\begin{array}{l}\text { 30months, } \\
\text { AWOD }\end{array}$ & $\begin{array}{l}\text { had a history of } \\
\text { breast cancer } \\
\text { (invasive lobular } \\
\text { carcinoma), } \\
\text { underwent a } \\
\text { mastectomy, and } \\
\text { received } \\
\text { tamoxifen for the } \\
\text { past five years. } \\
\text { received pelvic } \\
\text { and intracavitary } \\
\text { radiation. }\end{array}$ \\
\hline \multirow[t]{3}{*}{$\begin{array}{l}\text { Nisreen } \\
\text { Abushahin[3], } \\
2011\end{array}$} & 4 & 58 & $\begin{array}{l}\text { low abdominal } \\
\text { discomfort }\end{array}$ & Serous EIC & $\begin{array}{l}\text { THA and } \\
\text { BSO; laparoscopic } \\
\text { staging with } \\
\text { omentectomy }\end{array}$ & $\begin{array}{l}68 \\
\text { months, } \\
\text { AWOD }\end{array}$ & $\begin{array}{l}\text { No history of } \\
\text { breast cancer; } \\
\text { No hormone } \\
\text { replacement was } \\
\text { taken until the } \\
\text { age of } 55 \text { years; }\end{array}$ \\
\hline & & & & & & & $\begin{array}{l}\text { Endometriosis in } \\
\text { uterine serosa } \\
\text { and ovaries }\end{array}$ \\
\hline & & & & & & & $\begin{array}{l}\text { IHC: P53+++, } \\
\text { IMP3+++, ER+, } \\
\text { PR-, WT-1-, }\end{array}$ \\
\hline \multirow[t]{5}{*}{$\begin{array}{l}\text { Bingjian } \\
\text { Lu[10], } 2016\end{array}$} & 5 & 64 & $\begin{array}{l}\text { Left low } \\
\text { abdominal pain }\end{array}$ & $\begin{array}{l}\text { Serous } \\
\text { carcinoma }\end{array}$ & $\begin{array}{l}\text { TAH and BSO, } \\
\text { complete staging } \\
\text { surgery }\end{array}$ & NA & $\begin{array}{l}\text { Left ovary } \\
\text { metastasis, } \\
\text { leiomyoma, } \\
\text { endometriosis in } \\
\text { the rectum. }\end{array}$ \\
\hline & & & & & & & $\begin{array}{l}\text { ER-, PR-, CK7+++, } \\
\text { Ck20-, PAX-8+++, } \\
\text { WT1-, CA125++, } \\
\text { P53+++, } \\
\text { PTEN++, } \beta- \\
\text { catenin } \\
\text { membrane +, } \\
\text { P16+++, Ki67凶 } \\
80 \% .\end{array}$ \\
\hline & 6 & 55 & $\begin{array}{l}\text { Postmenopausal } \\
\text { vagina bleeding }\end{array}$ & $\begin{array}{l}\text { Minimal SC; } \\
\text { serous EIC; } \\
\text { EmGD }\end{array}$ & $\begin{array}{l}\text { TAH and BSO, and } \\
\text { complete staging } \\
\text { surgery }\end{array}$ & NA & $\begin{array}{l}\text { Lymphovascular } \\
\text { space invasion, } \\
\text { Leiomyoma. }\end{array}$ \\
\hline & & & & & & & 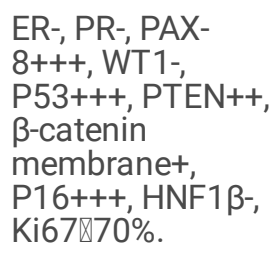 \\
\hline & 7 & 55 & Vaginal bleeding & $\begin{array}{l}\text { Serous EIC; } \\
\text { EmGD }\end{array}$ & $\begin{array}{l}\text { Radical resection } \\
\text { of the cervical } \\
\text { stump + BSO + }\end{array}$ & $\begin{array}{l}44 \\
\text { months, } \\
\text { AWOD }\end{array}$ & $\begin{array}{l}\text { ER-, PR-, PAX- } \\
8+++ \text { WT1-, }\end{array}$ \\
\hline
\end{tabular}

Page 5/12 


\begin{tabular}{|c|c|c|c|c|c|c|c|}
\hline & & & & & $\begin{array}{l}\text { complete staging } \\
\text { surgery }\end{array}$ & & $\begin{array}{l}\text { P53+++, P16+++, } \\
\text { Ki67 } 80 \% \\
\text { Left ovarian } \\
\text { endometriotic } \\
\text { cyst; } \\
\text { Endometriosis in } \\
\text { the rectum. }\end{array}$ \\
\hline $\begin{array}{l}\text { Chia-Hao Liu, } \\
\text { [6] } 2017\end{array}$ & 8 & 67 & $\begin{array}{l}\text { right inguinal } \\
\text { mass and } \\
\text { postmenopausal } \\
\text { bleeding. }\end{array}$ & $\begin{array}{l}\text { serous } \\
\text { carcinoma }\end{array}$ & $\begin{array}{l}\text { laparoscopic } \\
\text { complete staging } \\
\text { surgery and } \\
\text { inguinal LN } \\
\text { dissection. }\end{array}$ & $\begin{array}{l}8 \text { months, } \\
\text { AWOD }\end{array}$ & $\begin{array}{l}\text { metastatic } \\
\text { serous } \\
\text { carcinoma to the } \\
\text { inguinal lymph } \\
\text { node. }\end{array}$ \\
\hline Our case & 9 & 60 & $\begin{array}{l}\text { postmenopausal } \\
\text { bleeding. }\end{array}$ & $\begin{array}{l}\text { serous } \\
\text { carcinoma }\end{array}$ & $\begin{array}{l}\text { TAH and BSO, } \\
\text { complete staging } \\
\text { surgery }\end{array}$ & $\begin{array}{l}6 \text { months, } \\
\text { AWOD }\end{array}$ & $\begin{array}{l}\text { Small cell } \\
\text { carcinoma of the } \\
\text { ovary - } \\
\text { pulmonary type, }\end{array}$ \\
\hline
\end{tabular}

Abbreviation: NA, not available; TAH, total abdominal hysterectomy; BSO, bilateral salpingo-oophorectomy; LN, lymph node; AWOD, alive without disease; EIC, endometrial intraepithelial carcinoma; EmGD, endometrial glandular dysplasia;

There were no prominent symptoms, specific laboratory or imaging examination of malignant transformation of adenomyosis preoperatively, $[6,21,22]$ although some cases were found through cervical smears. [7, 23] The clinical manifestations of carcinoma originating from adenomyosis are the same as those of conventional adenomyosis, manifested as abnormal vaginal bleeding, menorrhea, or anemia. $[5,6,21,22,24]$ Therefore, the malignant transformation of adenomyosis has a high risk of missed diagnosis. The malignant transformation of adenomyosis is inside the myometrium rather than forming an exogenous mass, and there may lack positive findings in hysteroscopy and curettage specimens, any of these may lead to missed diagnosis[6]. Our patient came to the hospital due to gastrointestinal symptom and her main complaint for surgical treatment her was pelvic mass. There was no indication of malignant transformation of adenomyosis before the complete pathological examination. Nearly all the cases underwent surgery for other reasons and only diagnosed accurately after complete pathological examination. $[6,9,10$, 16]

Uterine serous carcinoma most demonstrate alterations in ERBB2, TP53, FBXW7, PPP2R1A, and of the phosphoinositide 3-kinase $(P I 3 K)$ pathway.[25] On the other hand, the etiology, pathogenesis or molecular alteration of the malignant transformation of adenomyosis are rarely known. At present, only a few studies suggest that there are gene changes and inactivation of specific tumor suppressor genes in adenomyosis, which may be related to its malignant transformation. This includes loss of heterozygosity ( $\mathrm{LOH}$ ), DNA mismatch repair genes, low expression of $\mathrm{Bcl}$-2. and epigenetic changes in the promoter region of the progesterone receptor gene.[26-28] Serous adenocarcinoma derived from adenomyosis also showed P53 mutant expression and WT-1 negativity, indicating that it may have similar molecular changes with serous adenocarcinoma of endometrial origin. Nevertheless, there is no study on molecular alteration of malignant transformation of adenomyosis into serous carcinoma because of its rarity.

Due to the low incidence of this disease and the existing studies mostly are case report, the risk factors of the malignant transformation of adenomyosis are still unclear. Reviewing the previous literature, we found that there is a patient with adenomyosis malignant transformation has taken tamoxifen for a long time in the past.[9] Coincidentally, there was also a SCOOPT case who had previously received tamoxifen treatment for breast cancer.[29] Therefore, receiving tamoxifen treatment may be a risk factor of malignant transformation of adenomyosis and SCOOPT.

Primary small cell carcinoma of the ovary is a highly malignant tumor, divided into two types: small cell carcinoma of the ovary the pulmonary type (SCCOPT) and the hypercalcemia type (SCCOHT). Both types are rare, but compared with SCCOHT, SCCOPT is rarer and only less than 30 cases have been reported. SCCOHT is often accompanied by elevated serum calcium level and may have the symptoms of hypercalcemia.[30] SCCOPT is similar to pulmonary small cell carcinoma and is considered to be a neuroendocrine tumor, and is consistent with pulmonary small cell carcinoma in morphology and immunophenotype. The case reported in this study is SCCOPT. 
It is necessary to exclude the metastatic cancer of the pulmonary, digestive tract, or cervix, etc., which requires the combination of the patient's gastrointestinal endoscopy, imaging, physical examination, intraoperative findings, morphology, and

immunohistochemical staining. Gastrointestinal endoscopy and enhanced CT scan of chest showed no tumorous lesions, and no other masses in the pelvic and abdominal cavity were seen during the operation in our case, which can rule out the possibility of metastasis. Although there were studies that have shown that primary small cell carcinoma of the ovary does not express TTF-1, $[31,32]$ its positivity does not exclude it as ovarian primary.[13]

Based on the clinical characteristics, morphological features, and immunohistochemical staining of this case, we can distinguish it from SCCOHT. First, SCCOPT does not have follicular-like spaces and large cell components.[12, 30, 33] Secondly, SMARCA4 always shows diffuse positivity in SCCOPT, while it is always negative in SCCOHT.[34, 35] On the other hand, the expression of vimentin is exactly the opposite of SMARCA4 in these two different types.[12] In addition, approximately $70 \%$ of SCCOHT patients generally have hypercalcemia that SCCOPT does not.[12, 14,36] According to previous reports, the average age of SCCOPT is 59 years old[36], while the average age of SCCOHT is 23.9-30years old.[30, 33]

SCCOPT also needs to be differentiated from ovarian germ cell tumors and lymphoma. Lymphoma specifically expresses lymphoma-related markers, such as LCA, Bcl-2, CD20, etc.[13] Ovarian germ cell tumors always showed positivity of germ cell markers, such as SALL-4 and OCT 3/4.[13]

There are studies using flow cytometry found out that SCCOPT were aneuploid or diploid,[36] while SCCOHT were all diploid. [30] Recent studies have shown that germline or somatic mutations in the SMARCA4 gene are highly correlated with SCCOHT.[35, $37,38]$ Unfortunately, there is currently no therapy for this mutation. There is only one literature that revealed TP53 mutations in 25 $\%$ of small cell carcinoma of ovary (SCCO) (1/4) patients and BRCA2 mutations in $50 \%$ of SCCO (1/2) patients by using NGS and Sanger sequencing of a 47-gene panel.[39] Although the authors declaim that the TP53 mutation is likely oncogenic, it is not persuasive to conclude that TP53 mutation is the representative molecular alteration of SCCOPT from only one case.

The prognosis of SCCOPT is very poor. Even for patients with FIGO stage IA, the long-term survival is only $30 \%$ to $40 \%$.[14] According to the prognosis of the disease previously reported by Eichhorn[36], 5 of the 7 cases died of the disease 1-13 months (average 8 months) after surgery. Because of the biological behavior similarity between the extrapulmonary and the lung small cell carcinoma, the treatment approaches of the two are generally similar.[40, 41]

\section{Conclusion}

Due to the low incidence of SCOOPT and malignant transformation of adenomyosis into serous adenocarcinoma, little is known about their etiology, pathophysiology, pathogenesis, and specific genetic changes. To the best of our knowledge, this is the first case which serous adenocarcinoma arising in adenomyosis synchronous with SCOOPT. Carefully and completely pathological examination, immunohistochemical staining, and imaging examination are essential to the final diagnosis. It is worth collecting more cases for systematic and further in-depth study to uncover their clinicopathological characteristics and molecular changes.

\section{Declarations}

Consent for publication

The patient agreed to the publication of this case.

Availability of data and materials

All data generated or analysed during this study are included in this published article.

Competing interests

The authors declare no conflicts of interest.

Funding

Page $7 / 12$ 
Not applicable.

Authors' contributions

Data collecting and analysis: Qiuyang Jing and Ying He.

Writing - original draft: Qiuyang Jing.

Writing - review \& editing: Ying He.

\section{References}

1. Rolly, Ueber einen Fall von Adenomyoma uteri mit Uebergang in Carcinom und Metastasenbildung. Archiv für Pathologische Anatomie und Physiologie und für Klinische Medicin, 1897. 150(3): p. 555-582.

2. Sampson and A. John, ENDOMETRIAL CARCINOMA OF THE OVARY, ARISING IN ENDOMETRIAL TISSUE IN THAT ORGAN. American Journal of Obstetrics \& Gynecology, 1925. 9(1): p. 111-114.

3. Abushahin, N., et al., Serous endometrial intraepithelial carcinoma arising in adenomyosis: a report of 5 cases. Int J Gynecol Pathol, 2011. 30(3): p. 271-81.

4. Ismiil, N.D., et al., Adenomyosis is associated with myometrial invasion by FIGO 1 endometrial adenocarcinoma. International Journal of Gynecological Pathology, 2007. 26(3): p. 278-283.

5. Yuan, H. and S. Zhang, Malignant transformation of adenomyosis: literature review and meta-analysis. Arch Gynecol Obstet, 2019. 299(1): p. 47-53.

6. Liu, C.H., et al., Serous carcinoma arising from adenomyosis. Taiwan J Obstet Gynecol, 2017. 56(5): p. 706-707.

7. Griffin, M., et al., Papillary serous carcinoma of the uterus arising in an adenomyoma. Acta Cytol, 1996. 40(4): p. 849-50.

8. Koshiyama, M., et al., Adenocarcinomas arising from uterine adenomyosis: a report of four cases. Int J Gynecol Pathol, 2002. 21(3): p. 239-45.

9. Izadi-Mood, N., et al., Papillary serous carcinoma arising from adenomyosis presenting as intramural leiomyoma. Arch Iran Med, 2007. 10(2): p. 258-60.

10. Lu, B., et al., Serous carcinoma arising from uterine adenomyosis/adenomyotic cyst of the cervical stump: a report of 3 cases. Diagn Pathol, 2016. 11(1): p. 46.

11. Matsuo, K., et al., Tumor Characteristics and Survival Outcome of Endometrial Cancer Arising in Adenomyosis: An Exploratory Analysis. Ann Surg Oncol, 2016. 23(3): p. 959-67.

12. Atienza-Amores, M., et al., Small cell carcinoma of the gynecologic tract: a multifaceted spectrum of lesions. Gynecol Oncol, 2014. 134(2): p. 410-8.

13. (editor), W.C.o.T.E.B., Female Genital Tumours: WHO Classification of Tumours 5th ed. 2020: International Agency for Research on Cancer.

14. Reed, N.S., et al., Gynecologic Cancer InterGroup (GCIG) consensus review for ovarian small cell cancers. Int J Gynecol Cancer, 2014. 24(9 Suppl 3): p. S30-4.

15. Koshiyama, M., T. Okamoto, and M. Ueta, The relationship between endometrial carcinoma and coexistent adenomyosis uteri, endometriosis externa and myoma uteri. Cancer Detect Prev, 2004. 28(2): p. 94-8.

16. Hsu, M.l., et al., Very Early Stage Adenocarcinoma Arising from Adenomyosis in the Uterus. Taiwanese Journal of Obstetrics Gynecology, 2006. 45(4): p. 346-349.

17. Baba, A., et al., Clear cell adenocarcinoma arising from adenomyotic cyst: A case report and literature review. J Obstet Gynaecol Res, 2016. 42(2): p. 217-23.

18. Scott, R.B., Malignant changes in endometriosis. Obstet Gynecol, 1953. 2(3): p. 283-9.

19. Colman, H.I. and A.H. Rosenthal, Carcinoma developing in areas of adenomyosis. Obstet Gynecol, 1959. 14: p. 342-8.

20. Machida, $\mathrm{H}$. , et al., Endometrial cancer arising in adenomyosis versus endometrial cancer coexisting with adenomyosis: are these two different entities? Arch Gynecol Obstet, 2017. 295(6): p. 1459-1468.

Page $8 / 12$ 
21. Mao, X., W. Zheng, and W. Mao, Malignant changes in adenomyosis in patients with endometrial adenocarcinoma: A case series. Medicine (Baltimore), 2017. 96(43): p. e8336.

22. Zouzoulas, O.D., et al., Correlation between Adenomyosis and Endometrial cancer: 6-year experience of a single center. Facts Views Vis Obgyn, 2018. 10(3): p. 147-152.

23. Woodruff, J.D., Y.S. Erozan, and R. Genadry, Adenocarcinoma arising in adenomyosis detected by atypical cytology. Obstet Gynecol, 1986. 67(1): p. 145-8.

24. Koike, N., et al., Pathogenesis and malignant transformation of adenomyosis (review). Oncol Rep, 2013. 29(3): p. 861-7.

25. Lee, E.K., et al., Uterine serous carcinoma: Molecular features, clinical management, and new and future therapies. Gynecol Oncol, 2021. 160(1): p. 322-332.

26. Jones, R.K., R.F. Searle, and J.N. Bulmer, Apoptosis and bcl-2 expression in normal human endometrium, endometriosis and adenomyosis. Hum Reprod, 1998. 13(12): p. 3496-502.

27. Jichan, N., L. Xishi, and S.W. Guo, Promoter hypermethylation of progesterone receptor isoform B (PR-B) in adenomyosis and its rectification by a histone deacetylase inhibitor and a demethylation agent. Reprod Sci, 2010. 17(11): p. 995-1005.

28. Goumenou, A.G., et al., Loss of heterozygosity in adenomyosis on hMSH2, hMLH1, p16Ink4 and GALT loci. Int J Mol Med, 2000. 6(6): p. 667-71.

29. Yin, L., et al., Primary ovarian small cell carcinoma of pulmonary type with coexisting endometrial carcinoma in a breast cancer patient receiving tamoxifen: A case report and literature review. Medicine (Baltimore), 2018. 97(23): p. e10900.

30. Young, R.H., E. Oliva, and R.E. Scully, Small cell carcinoma of the ovary, hypercalcemic type. A clinicopathological analysis of 150 cases. Am J Surg Pathol, 1994. 18(11): p. 1102-16.

31. Bing, Z. and P. Adegboyega, Metastasis of small cell carcinoma of lung into an ovarian mucinous neoplasm: immunohistochemistry as a useful ancillary technique for diagnosis and classification of rare tumors. Applied immunohistochemistry \& molecular morphology: AIMM, 2005. 13 1: p. 104-7.

32. Oneda, E., et al., Differential Diagnosis of Small Cell Carcinoma of the Ovary or Ovarian Metastases of Small Cell Carcinoma of the Lung: A Case Report and Review of the Literature. Case Rep Oncol, 2020. 13(2): p. 822-828.

33. Callegaro-Filho, D., et al., Small cell carcinoma of the ovary-hypercalcemic type (SCCOHT): A review of 47 cases. Gynecol Oncol, 2016. 140(1): p. 53-7.

34. Conlon, N., et al., Loss of SMARCA4 Expression Is Both Sensitive and Specific for the Diagnosis of Small Cell Carcinoma of Ovary, Hypercalcemic Type. Am J Surg Pathol, 2016. 40(3): p. 395-403.

35. Witkowski, L., et al., Germline and somatic SMARCA4 mutations characterize small cell carcinoma of the ovary, hypercalcemic type. Nat Genet, 2014. 46(5): p. 438-43.

36. Eichhorn, J.H., R.H. Young, and R.E. Scully, Primary ovarian small cell carcinoma of pulmonary type. A clinicopathologic, immunohistologic, and flow cytometric analysis of 11 cases. Am J Surg Pathol, 1992. 16(10): p. 926-38.

37. Ramos, P., et al., Small cell carcinoma of the ovary, hypercalcemic type, displays frequent inactivating germline and somatic mutations in SMARCA4. Nat Genet, 2014. 46(5): p. 427-9.

38. Jelinic, P., et al., Recurrent SMARCA4 mutations in small cell carcinoma of the ovary. Nat Genet, 2014. 46(5): p. 424-6.

39. Yaghmour, G., et al., Genomic alterations in neuroendocrine cancers of the ovary. J Ovarian Res, 2016. 9(1): p. 52.

40. Walenkamp, A.M., G.S. Sonke, and D.T. Sleijfer, Clinical and therapeutic aspects of extrapulmonary small cell carcinoma. Cancer Treat Rev, 2009. 35(3): p. 228-36.

41. Brennan, S., Should extrapulmonary small cell cancer be managed like small cell lung cancer? Cancer, 2010. 75.

\section{Figures}




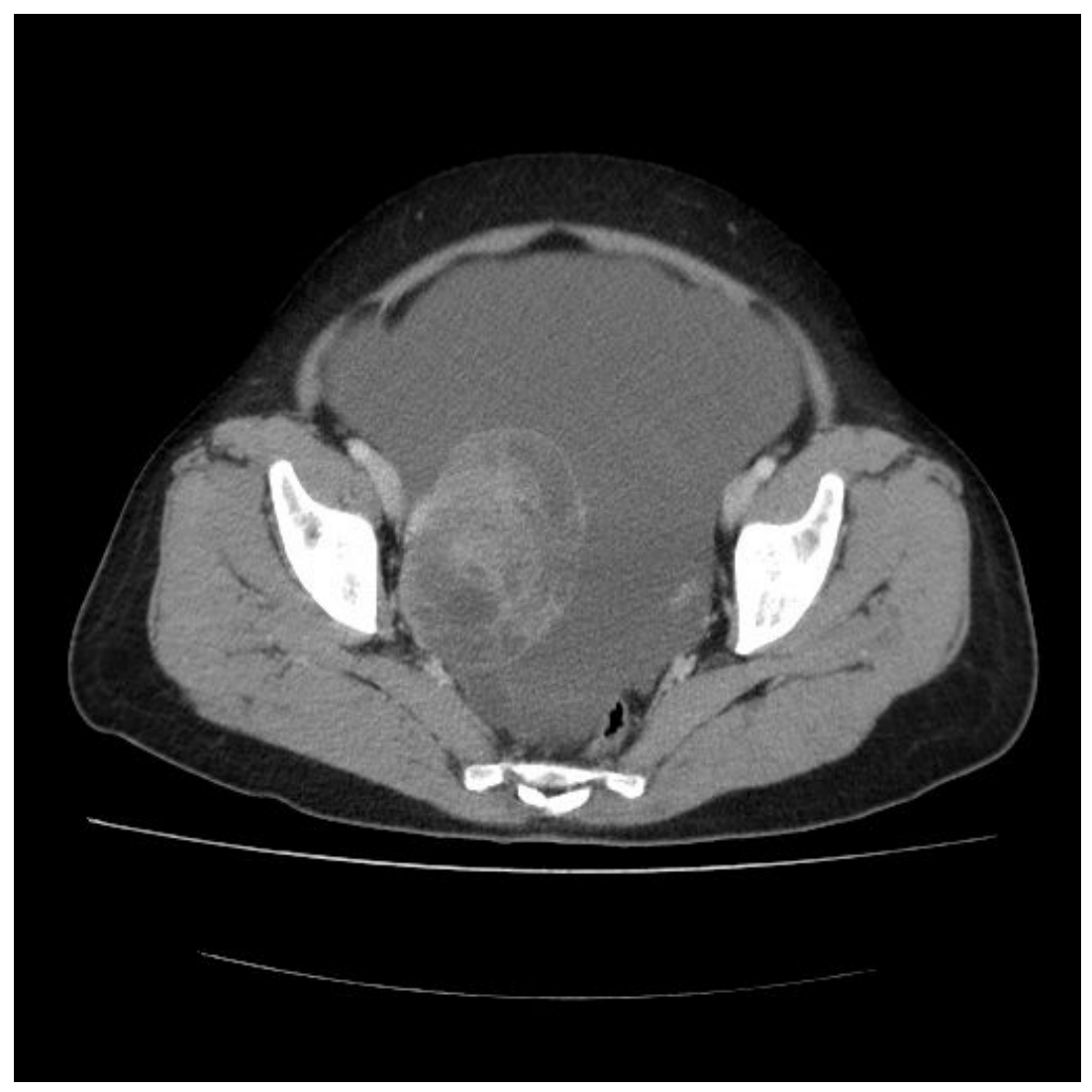

Figure 1

CT scan of pelvic shows a solid- cystic heterogeneous mass

\section{Figure 2}

Small cell carcinoma of the ovary; A. hematoxylin and eosin stain (40X); B. hematoxylin and eosin stain, mitotic figures and karyorrhexis are seen (400X); C. SMARCA4 positivity (200X); D. CgA positivity(200X); E. Syn positivity(200X); F. CD56 positivity(200X). 

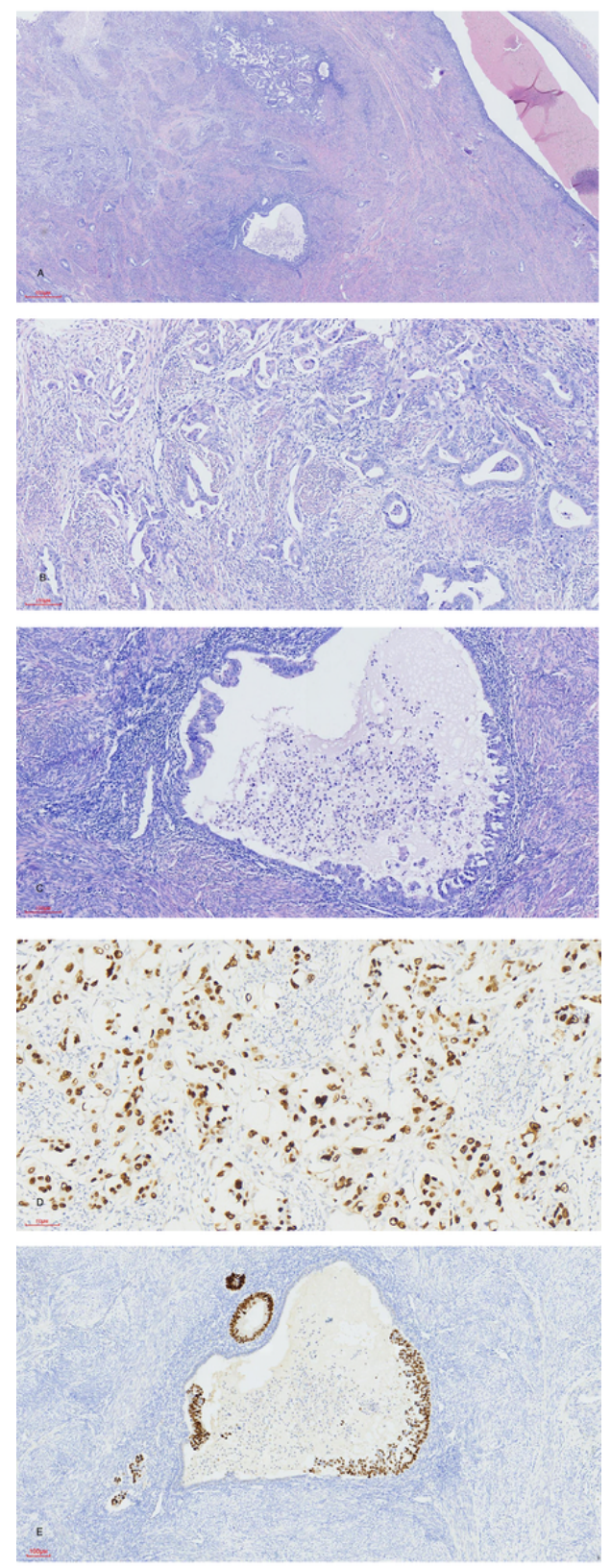

Figure 3

Serous carcinoma originating from adenomyosis; A. adenomyosis in the middle lower part, adenomyosis cystic in the right part, serous carcinoma in the upper and left part. B. serous carcinoma, C. ectopic endometrium glandular and stroma, some glandular with atypic proliferation, D. P53 diffuse strong positivity of serous carcinoma. E. This figure shows the different expression of p53 in the same gland. The normal glandular epithelium is wild type, while the atypical glandular epithelium is mutant type. 


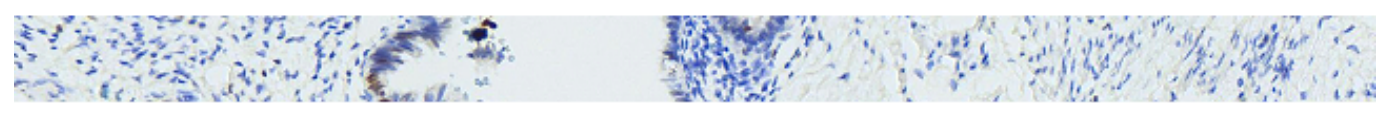

Figure 4

A. p53 wild-type expression of fallopian epithelium, B. p53 wild-type expression of eutopic endometrium. 